\title{
COUNTY UNEMPLOYMENT IN GEORGIA: THE CAUSES AND POTENTIAL ROLE FOR ECONOMIC DEVELOPMENT POLICY
}

\author{
Mark D. Partridge and Dan S. Rickman ${ }^{*}$
}

\begin{abstract}
Economic development has been uneven within many states, often resulting in wide geographic disparities in unemployment. Using county-level panel data, this study examines variation in unemployment rates within Georgia to determine the potential role that state and local economic development policy may play in reducing unemployment in underdeveloped areas. Thus, a particular concern of the study is whether metropolitan areas and central cities have different unemployment rates, once other characteristics are accounted for. The findings of the study do not support urban areas, or, alternatively, very rural areas, as inherently having different unemployment rates. Thus, state economic development policy need not focus on enhancing one type of area over the other to reduce the state unemployment rate. However, the findings suggest the need for increasing high school attainment rates, providing affordable day-care, and addressing the high unemployment among African-Americans.
\end{abstract}

\section{INTRODUCTION}

State and local policymakers have increasingly been confronted with the problem of uneven economic growth and development within their states. Georgia represents a typical case in that robust economic growth is centered in greater Atlanta, its largest, or first-tier city, but it is much less spectacular outside Atlanta. Even in the smaller metropolitan areas, economic growth has been unsteady, and in much of rural Georgia, growth has at best stagnated, if not outright declined. This uneven growth has led commentators to voice concerns that there are "two" Georgias-greater Atlanta and the rest of Georgia.

Georgia is not the only state experiencing uneven economic development. For example, in Illinois, Chicago's economy has fared well, but the much smaller second-tier cities have struggled and much of the rest of the state has suffered. Similar examples from across the United States are numerous.

Correspondingly, state policymakers in recent years are not just trying to spur economic development in their states, but they are also interested in targeting economic growth to underdeveloped areas. For example, in an attempt to broaden economic development to second-tier cities, policymakers advertise that most of these cities have lower wages and land costs than first-tier cities (e.g., see Salwen,

\footnotetext{
*Assistant Professor of Economics at St. Cloud State University, St. Cloud, MN, and Oklahoma Gas and Electric Chair in Regional Economic Analysis at Oklahoma State University, respectively. The authors wish to thank Jamie Partridge for her valuable assistance with the study.
} 
1995). Nationally, several targeted strategies have been proposed, such as improving the educational system in underdeveloped areas and directly encouraging economic development in the second-tier cities.

To improve their economic development efforts, Georgia and North Carolina have both created several development regions. In North Carolina, there are seven economic development regions (Gepfert 1994), while Georgia has eleven districts (The Governor's Development Council 1994). A goal behind the formation of these regions is to encourage economic activity in lagging areas. In contrast to past efforts in many states where economic development regions have been defined by convenience or political expediency, the economic development regions in North Carolina and Georgia are much closer to being distinct economic regions with an important regional commercial center(s) in each of them.

Figure 1 shows the eleven regions for Georgia and lists the major commercial center(s) in each district. Also shown in Figure 1 are the unemployment rates for the eleven regions in 1993, in which the five regions with the lowest unemployment rates are distinguished from the six regions with the highest unemployment rates. Regarding unemployment, the map shows that these regions do have an economic basis. First, Region 3, which is made up entirely of counties in the Atlanta metropolitan area, has the lowest unemployment rate. Regions that border Atlanta also have lower unemployment rates. South Georgia counties, in contrast, have the highest levels of unemployment. Thus, as far as unemployment is concerned, the Atlanta and "other Georgia" account is a little too simplistic, because although the Atlanta metropolitan area does have a very low unemployment rate, there are spillovers into neighboring regions. Nonetheless, what apparently is true about the "two"-Georgia account is that South Georgia has trailed the rest of the state. ${ }^{1}$

In the text that follows, we will investigate unemployment rate differences within Georgia. Our goal is to explain county unemployment rate differentials by examining a multitude of economic, social, demographic, and regional effects. Therefore, our results should be of interest to policymakers who wish to understand the causes and possible solutions for unbalanced economic development within a state. A unique feature of our approach is that the state economic development districts will be directly used in our empirical design. Thus, practitioners may be interested in our empirical analysis because it can be duplicated in assessing economic conditions in other sub-state regions. Policy issues that will receive special attention include the issue of whether employment growth in itself is a solution for unemployment problems or whether unemployment differences are caused by more structural problems, such as inadequate education. Thus, we can address whether traditional "smokestack" chasing is a reasonable solution to unemployment problems or whether long-run programs to improve the skills of 
the labor-force are in order. Finally, we also will address whether first-tier cities possess such major advantages that a goal of balanced economic development within a state may be unattainable.

\section{FIGURE 1}

Georgia Development Regions

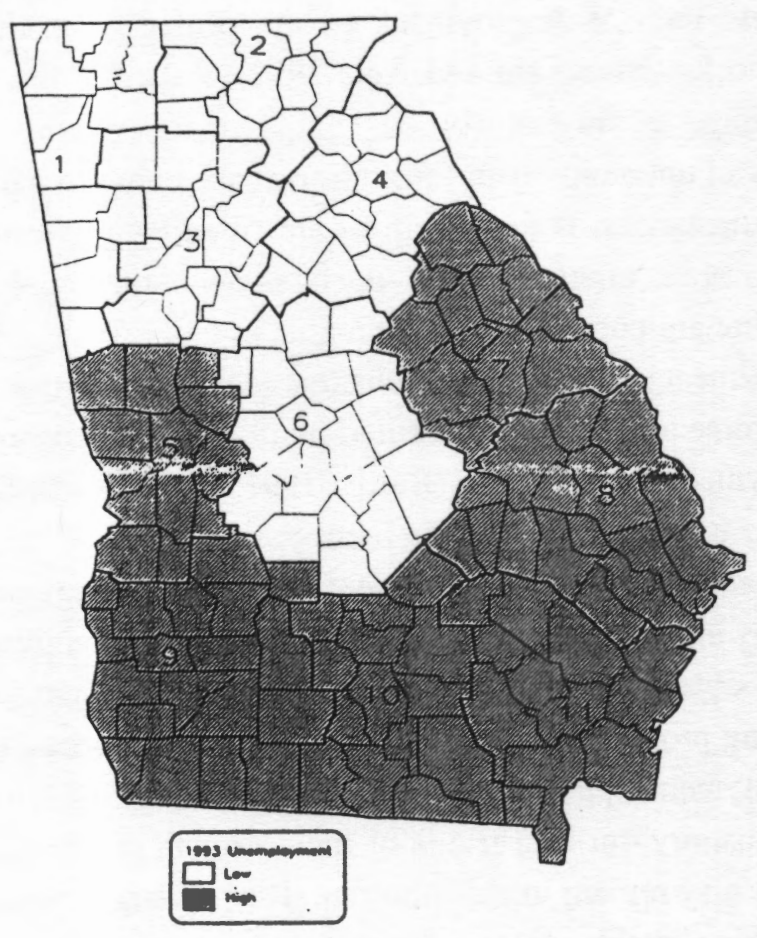

\begin{tabular}{lll} 
Region & Maior Commercial Area & 1993 Unemployment Rate \\
\cline { 3 - 3 } 2 & Dalton, Rome (Atlanta, Chattanooga,TN) & $6.4 \%$ \\
3 & Gainesville (Atlanta) & $5.7 \%$ \\
4 & Atlanta & $5.4 \%$ \\
5 & Athens (Atlanta) & $6.0 \%$ \\
6 & Columbus & $7.3 \%$ \\
7 & Macon (Atlanta) & $6.3 \%$ \\
8 & Augusta & $7.3 \%$ \\
9 & Savannah & $6.9 \%$ \\
10 & Albany & $8.4 \%$ \\
11 & Baldosta & $7.0 \%$ \\
& Brunswick, Waycross (Jacksonville,FL) & $6.9 \%$
\end{tabular}




\section{A CONCEPTUAL MODEL OF COUNTY UNEMPLOYMENT IN GEORGIA}

As a reduced form outcome of the interaction of labor demand and labor supply, the unemployment rate is determined by a multitude of factors. Foremost in the minds of many economic development practitioners is the influence of employment growth. For example, metropolitan Atlanta has experienced stronger employment growth than other parts of Georgia. Strong employment growth in large metropolitan areas such as Atlanta is often attributed to location advantages and agglomeration effects. Thus, if employment growth primarily results from positive labor demand shocks (Blanchard and Katz 1992), Atlanta's unemployment rate may be lower simply because of its robust employment growth.

However, reductions in unemployment through increased employment may be limited in certain circumstances. If the new jobs are filled by previously unemployed persons in the area, unemployment declines with the employment growth. Conversely, if there are corresponding increases in labor force participation rates, or if the employment growth creates jobs that require skills that do not match those of the labor force and the jobs are filled by in-migrants, the employment effect on unemployment is mitigated (Bartik 1991, 1993; Partridge and Rickman 1995a). This may be particularly true in metropolitan areas.

Besides possible direct effects on unemployment of employment growth differences, other reasons may underlie metropolitan Atlanta's lower unemployment. Most of these relate to possible natural rate differences in unemployment. For example, labor force matching problems may be mitigated in Atlanta because of its greater diversity of employment opportunities (Malizia and Ke 1993). Though this may be somewhat transitory during periods of rapid growth or decline, persistent matching problems may remain in the long run. Thus, if larger population centers have fewer matching problems, economic development policy should focus on enhancing the other metropolitan areas in the state. However, the reduction in unemployment may not occur until some threshold of urbanization is attained, after which unemployment declines. Finally, there also is concern that the central cities within metropolitan areas, including Atlanta, do not benefit as much with increased urbanization.

Another reason that unemployment may be related to urbanization is that household amenities can differ between urban and rural areas. On the one hand, higher levels of household amenities in metropolitan areas such as cultural and recreational opportunities may lead to greater net in-migration and consequently higher unemployment (Marston 1985; Herzog and Schlottmann 1986). Conversely, pollution, crime and other congestion effects may occur at some level of urbanization (Herzog and Schlottmann 1993), reducing the unemployment rate 
through net out-migration. Thus, from a household amenity perspective, it is not clear whether unemployment should be lower or higher in metropolitan areas. The net effect probably depends on the size of the metropolitan area.

In addition, producer amenities may be related to urbanization, acting as a compensating differential for low unemployment rates. That is, low unemployment rates may be associated with higher labor costs for firms and producer amenities compensate firms for the higher costs (Hall 1972; Marston 1985). Yet, if household and producer amenities are correlated across areas, the net amenity influence on the unemployment rate is ambiguous. For example, as a consumer disamenity, crime increases out-migration, reducing unemployment, while as a producer disamenity, it reduces labor demand and increases unemployment. Similar statements could be made about traffic congestion.

The wage structure and industrial composition of a region can also influence relative unemployment rates. Regarding wages, simple Keynesian models suggest that negative economic shocks cause greater unemployment because of downward wage rigidity. Likewise, efficiency wage models, where productivity and wage rates are positively related, suggest that a region's wage structure and its unemployment are associated (Stiglitz 1987). Unfortunately, average hourly wage rates are unavailable at the county level for Georgia. However, the model we implement does account for numerous determinants of wages. In particular, industry composition represents an important determinant of a region's wage structure. For example, Katz and Summers (1989) found large wage differentials between industries, even after accounting for a multitude of individual and industry characteristics. Moreover, Katz and Summers found that these wage differentials were persistent, where they suggested that efficiency wage theories are possible explanations for industry wage differentials. Thus, variations in industry composition should influence relative county unemployment rates because industry mix is an important determinant of a county's wage structure.

In addition, industry composition also can influence unemployment in other ways. For example, cyclically sensitive industries, such as manufacturing, can have greater variations in employment (McGee, 1985), which may increase frictional and structural unemployment. Also, since manufacturing jobs are relatively higher paying, workers may queue up for manufacturing jobs, causing unemployment to be higher through a wait unemployment effect (Summers, 1986). On the other hand, a disproportionate share of high-wage industries may reduce unemployment because the additional income generates more jobs through multiplier effects (Partridge and Rickman, 1995b). Similarly, employment in other sectors may be associated with differing unemployment rates. Unemployment is typically higher among construction workers, but lower among workers in the service and trade sectors. 
Another potential source of unemployment rate differences is the education level of the labor force in each county. Educational attainment affects not only the quality of the labor force and the corresponding employment growth, but also the frequency and duration of unemployment. With the increasing relative demand for skilled workers in the U.S. economy, less educated workers may have greater difficulty finding jobs (Katz and Murphy, 1992).

Constraints on worker mobility also may lead to higher unemployment. There may be both monetary and psychic costs to moving (Herzog and Schlottmann 1981; Douglas and Wall 1993). In particular, individuals may possess a "sense of place," or strong attachment to their communities. According to Bolton (1992), a sense of place also has economic value to individuals, which may be equal in magnitude to the monetary costs of moving. For example, physical and social familiarity with a community are valuable because they encourage trust in market and non-market relationships, reducing transactions costs. Thus, during economic downturns, people losing their jobs may be reluctant to leave in search of employment elsewhere, leading to increased unemployment. In stable, more rural counties, larger proportions of the population have strong ties to the area.

Several demographic factors also are thought to influence county unemployment rates. First, the percent of the labor force that is male may affect unemployment. Since males have a greater attachment to the labor force, as evidenced by their higher labor force participation rates nationally (Statistical Abstract of the United States: 1994), they are more likely to remain in the labor force if they lose their jobs, leading to a higher unemployment rate. Similarly, women with children six years old or younger are more likely to be unemployed nationally, particularly single women (Statistical Abstract of the United States: 1994); thus, counties with higher percentages of women with young children may have higher unemployment. A lack of affordable day care, leading to conflicts between child care and the workplace, could be a likely cause. Because of potential conflicts, employers' hiring practices also may discriminate against women with young children at home. However, to the extent that the women eventually withdraw from the labor force, the effect on unemployment is mitigated. Nationally, participation rates are lower for single women with children under six than for other single women, while the participation rates are unaffected for married women with children under six, relative to other married women (Statistical Abstract of the United States: 1994).

Because of possible discrimination or differences in tastes and preferences for market work, unemployment rates of African-Americans is higher nationally (Statistical Abstract of the United States: 1994), and hence, may be higher in Georgia counties with a larger African-American population share. Similarly, since unemployment is higher among teenagers, the share of the labor force less 
than eighteen years old may increase the average unemployment rate. Alternatively, combined with the number of retirees, an increased number of children implies a smaller labor supply for a given labor demand, reducing unemployment. In addition, a large proportion of retirees in the population also may represent a stimulus to labor demand.

\section{EMPIRICAL MODEL}

Given the various possible explanations for unemployment differences across Georgia discussed above, an estimable equation for the county unemployment rate $\left(\mathrm{U}_{\mathrm{it}}\right)$, linear in the parameters, can be written as:

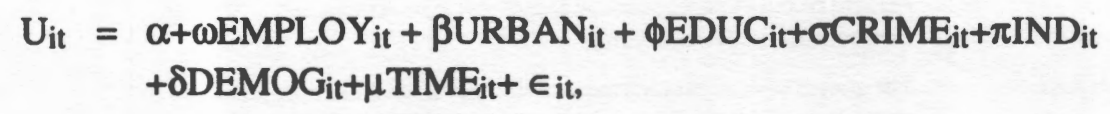

where i denotes county and t denotes time period, EMPLOY is employment growth relative to that of the nation, URBAN is a vector of time-invariant variables representing urbanization effects, EDUC contains various categories of educational attainment, CRIME denotes amenity effects on unemployment associated with the crime rate, IND contains measures of industry composition and DEMOG is a vector of demographic characteristics. TIME is a vector of annual fixed effects used to account for nationwide and statewide cyclical and structural influences on the county unemployment rate. The error term is denoted by $\epsilon$, while $\alpha, \omega, \beta, \phi, \sigma, \pi, \delta, \mu$ denote coefficient vectors.

The variable definitions and sources are given in Table 1. Unemployment is measured for all 159 counties in Georgia from 1980 to 1993. Although some independent variables are purely cross-sectional, most others also contain time-series variation. Moreover, except for the employment variables, all independent variables are measured at the county level. Employment in this study is measured at the eleven-region level within Georgia. This has the advantage of capturing crosscounty employment commuting patterns. ${ }^{2}$

Included in URBAN is a dummy variable (ATLMETRO) that takes a value of 1 if the county is in the Atlanta metropolitan area and zero otherwise. Similarly, a dummy variable (OTHMETRO) is included that has a value of 1 if the county is in one of the other metropolitan areas in Georgia. ${ }^{3}$ A final dummy variable is specified for counties that contain the central city (CENTRAL) of a metropolitan area. The URBAN variables will capture unmeasured urbanization effects on unemployment, such as reduced labor force matching problems, that are not accounted for by other characteristics associated with urban areas. An example of 
TABLE 1

Variable Definitions and Sources

\begin{tabular}{ll} 
VARIABLE & DEFINITION AND SOURCE \\
\hline UNEMP & $\begin{array}{l}\text { County unemployment rate for } 1980 \text { to 1993. Source: Georgia Department } \\
\text { of Labor. }\end{array}$
\end{tabular}

EMPLOY

ATLMETRO

OTHMETRO

CENTRAL

CRIME of Labor.

Growth in total nonfarm employment for the region containing the county, relative to the nation for 1977 to 1993. Source: Georgia Department of Labor and U.S. Employment and Earnings.

1 if the county is in the Atlanta metropolitan area in 1993; 0 otherwise.

1 if the county is in a metropolitan area other than Atlanta in 1993; 0 otherwise.

1 if the county contains a central city; 0 otherwise.

Total annual criminal offenses known to police per 1,000 people, linearly interpolated or extrapolated using 1980 and 1992 as endpoints.

Source: County and City Data Book, U.S. Department of Commerce.

AFRAM

Percent of the 1990 population that is African-American.

Source: Census of Population.

INDUSTRY SHARES

The shares of total employment in the region that are accounted for by: agriculture (FARMSHR); construction (CONSTSHR); manufacturing (MANUSHR); wholesale and retail trade (TRADE); and services (SERVSHR). Source: Georgia Department of Labor.

HERFIN

A Herfindahl index calculated as the sum of the square of employment shares in percent of all two-digit manufacturing sectors and one-digit nonmanufacturing sectors for 1980-1993. Source: Georgia Department of Labor.

UNDER 18

The percent of the population under the age of 18 in the county, linearly interpolated or extrapolated using 1980 and 1990 as endpoints. Source: Census of Population.

OVER64

The percent of the population over the age of 64 in the county, linearly interpolated or extrapolated using 1980 and 1990 as endpoints. Source: Census of Population.

LT9ED

The county percent of the adult population 25 years and older that have less than a ninth grade education, linearly interpolated or extrapolated using 1980 and 1990 as endpoints. Source: County and City Data Book, U.S. Department of Commerce.

HSDROP

The county percent of the adult population 25 years and older that completed the ninth grade but did not graduate from high school, linearly interpolated or extrapolated using 1980 and 1990 as endpoints. Source: County and City Data Book, U.S. Department of Commerce.

COLLEGE

The county percent of the adult population 25 years and older that graduated from college, linearly interpolated or extrapolated using 1980 and 1990 as endpoints. Source: County and City Data Book, U.S. Department of Commerce.

MALELF

The percent of the civilian labor force in the county that is male, linearly interpolated or extrapolated using 1980 and 1990 as endpoints.

Source: County and City Data Book, U.S. Department of Commerce.

FEMWCHU6

The percent of women over the age of 16 that have children under the age of 7, linearly interpolated or extrapolated using 1980 and 1990 as endpoints. Source: Census of Population.

HOMES

Percent of the 1990 population living in the same residence as five years before. Source: Census of Population.

BORNINST

Percent of the 1990 population born in the state of residence.

Source: Census of Population. 
this approach is the study by Carlino and Mills (1987), which found that after controlling for measurable characteristics of metropolitan areas, employment and population did not relatively decline in metropolitan areas in the 1970s.

Three categories of educational attainment are included. They are the percent of the adult population over 25 years of age that have (1) less than a ninth grade education (LT9ED); (2) completed ninth grade but did not graduate from high school (HSDROP); and (3) graduated from college (COLLGRAD). The omitted category is those who graduated from high school but did not receive a Bachelor's degree. Thus, each education coefficient should be interpreted as the effect of increasing that category 1 percent while reducing the category of high school graduates without a college degree by 1 percent.

CRIME is measured as the sum of the number of reported property and violent crimes per thousand people of the population. Also related to migration effects and natural rate differences in unemployment is the geographic mobility of workers. Geographic mobility is measured by the percent of the population living in the same residence for the past five years (HOME5) and the percent of the population that was born in the state (BORNINST). Psychic costs of moving are believed to be higher for those who have lived in the county the longest and are native to the state.

Industry structure is measured by the employment shares in manufacturing (MANUSHR), construction (CONSTSHR), trade (TRADESHR) and services (SERVSHR). In addition, because of the predominance of agriculture in many counties, the percent of employment engaged in farming (FARMSHR) is included. As a measure of industry concentration of an area, a Herfindahl index is calculated as the sum of various one- and two-digit industry employment shares (in percent) squared (HERFIN). ${ }^{4}$ Areas with high concentrations of particular industries will have a greater HERFIN, and could suffer from more employment instability and higher unemployment.

Finally, a series of demographic variables are included. The age of the population is accounted for by the percent of the population over sixty-four (OVER64) and under eighteen (UNDER18). The percent of the population that is African-American (AFRAM), the percent of the labor force that is male (MALELF), and the percent of women over the age of sixteen with children six years old or younger (FEMWCHU6) are also included as demographic controls.

\section{EMPIRICAL RESULTS}

The first column of Table 2 reports the means and standard deviations of the variables. These are based on both the cross-section variation across the 159 
TABLE 2

Unemployment Equation Econometric Estimates (absolute value of $t$-statistics in parentheses)

\begin{tabular}{|c|c|c|c|c|c|}
\hline VARIABLE & $\begin{array}{c}\text { MEAN } \\
\text { (STD DEV) } \\
\text { (1) }\end{array}$ & $\begin{array}{l}\text { OLS-I } \\
\text { (2) }\end{array}$ & $\begin{array}{l}\text { OLS-II } \\
\text { (3) }\end{array}$ & $\begin{array}{l}\text { OLS-III } \\
\text { (4) }\end{array}$ & $\begin{array}{c}\text { RANDOM } \\
\text { EFFECTS } \\
\text { (5) }\end{array}$ \\
\hline UNEMP & $\begin{array}{r}0.078 \\
(0.031)\end{array}$ & & & & \\
\hline CONSTANT & & $\begin{array}{r}-0.172 \\
(5.55)\end{array}$ & $\begin{array}{l}-0.038 \\
(0.61)\end{array}$ & $\begin{array}{l}-0.047 \\
(0.74)\end{array}$ & $\begin{array}{l}0.069 \\
(1.09)\end{array}$ \\
\hline EMPLOY & $\begin{array}{r}0.018 \\
(0.032)\end{array}$ & $\begin{array}{l}-0.093 \\
(3.87)\end{array}$ & $\begin{array}{l}-0.115 \\
(4.32)\end{array}$ & $\begin{array}{l}-0.217 \\
(5.08)\end{array}$ & $\begin{array}{c}-0.218 \\
(5.76)\end{array}$ \\
\hline EMPLOY(-1) & $\begin{array}{r}0.014 \\
(0.032)\end{array}$ & $\begin{array}{r}-0.057 \\
(2.47)\end{array}$ & $\begin{array}{l}-0.074 \\
(3.01)\end{array}$ & $\begin{array}{r}-0.175 \\
(4.08)\end{array}$ & $\begin{array}{l}-0.176 \\
(4.62)\end{array}$ \\
\hline EMPLOY(-2) & $\begin{array}{r}0.012 \\
(0.032)\end{array}$ & $\begin{array}{r}-0.061 \\
(2.68)\end{array}$ & $\begin{array}{l}-0.081 \\
(3.33)\end{array}$ & $\begin{array}{r}-0.179 \\
(4.14)\end{array}$ & $\begin{array}{r}-0.180 \\
(4.69)\end{array}$ \\
\hline ATLMETRO & $\begin{array}{r}0.126 \\
(0.332)\end{array}$ & $\begin{array}{r}-0.44 \mathrm{E}-02 \\
(1.64)\end{array}$ & $\begin{array}{r}-0.87 \mathrm{E}-02 \\
(2.69)\end{array}$ & $\begin{array}{r}-0.84 \mathrm{E}-02 \\
(2.60)\end{array}$ & $\begin{array}{r}-0.83 \mathrm{E}-02 \\
(1.23)\end{array}$ \\
\hline OTHMETRO & $\begin{array}{r}0.120 \\
(0.324)\end{array}$ & $\begin{array}{r}-0.30 \mathrm{E}-02 \\
(1.23)\end{array}$ & $\begin{array}{r}-0.42 E-03 \\
(0.17)\end{array}$ & $\begin{array}{r}-0.13 E-02 \\
(0.52)\end{array}$ & $\begin{array}{r}-0.16 \mathrm{E}-02 \\
(0.31)\end{array}$ \\
\hline CENTRAL & $\begin{array}{r}0.044 \\
(0.205)\end{array}$ & $\begin{array}{r}0.25 \mathrm{E}-02 \\
(0.64)\end{array}$ & $\begin{array}{r}0.17 \mathrm{E}-02 \\
(0.42)\end{array}$ & $\begin{array}{r}0.15 \mathrm{E}-02 \\
(0.38)\end{array}$ & $\begin{array}{r}-0.14 \mathrm{E}-03 \\
(0.02)\end{array}$ \\
\hline CRIME & $\begin{array}{r}29.2 \\
(21.9)\end{array}$ & $\begin{array}{r}0.13 \mathrm{E}-03 \\
(3.07)\end{array}$ & $\begin{array}{r}0.12 \mathrm{E}-03 \\
(2.88)\end{array}$ & $\begin{array}{r}0.12 \mathrm{E}-03 \\
(2.75)\end{array}$ & $\begin{array}{r}0.86 \mathrm{E}-04 \\
(1.37)\end{array}$ \\
\hline AFRAM & $\begin{array}{r}27.4 \\
(17.3)\end{array}$ & $\begin{array}{r}0.25 \mathrm{E}-03 \\
(4.90)\end{array}$ & $\begin{array}{r}0.40 \mathrm{E}-03 \\
(6.68)\end{array}$ & $\begin{array}{r}0.41 \mathrm{E}-03 \\
(6.83)\end{array}$ & $\begin{array}{r}0.46 \mathrm{E}-03 \\
(3.82)\end{array}$ \\
\hline FARMSHR & $\begin{array}{r}5.0 \\
(3.45)\end{array}$ & $\begin{array}{r}-0.10 \mathrm{E}-02 \\
(3.87)\end{array}$ & $\begin{array}{r}-0.96 \mathrm{E}-03 \\
(3.33)\end{array}$ & $\begin{array}{r}-0.89 \mathrm{E}-03 \\
(3.11)\end{array}$ & $\begin{array}{r}-0.41 \mathrm{E}-03 \\
(0.72)\end{array}$ \\
\hline MANUSHR & $\begin{array}{r}0.134 \\
(0.128)\end{array}$ & $\begin{array}{r}-0.42 \mathrm{E}-02 \\
(1.89)\end{array}$ & $\begin{array}{r}-0.158 \\
(2.13)\end{array}$ & $\begin{array}{l}-0.152 \\
(2.05)\end{array}$ & $\begin{array}{l}-0.154 \\
(2.41)\end{array}$ \\
\hline SERVSHR & $\begin{array}{r}0.139 \\
(0.036)\end{array}$ & $\begin{array}{l}0.078 \\
(1.50)\end{array}$ & $\begin{array}{l}-0.206 \\
(2.25)\end{array}$ & $\begin{array}{r}-0.197 \\
(2.15)\end{array}$ & $\begin{array}{l}-0.199 \\
(2.54)\end{array}$ \\
\hline TRADESHR & $\begin{array}{r}0.139 \\
(0.029)\end{array}$ & $\begin{array}{r}-0.039 \\
(0.75)\end{array}$ & $\begin{array}{l}-0.328 \\
(2.85)\end{array}$ & $\begin{array}{r}-0.325 \\
(2.82)\end{array}$ & $\begin{array}{c}-0.329 \\
(3.30)\end{array}$ \\
\hline CONSTSHR & $\begin{array}{r}0.047 \\
(0.013)\end{array}$ & $\begin{array}{l}0.130 \\
(1.93)\end{array}$ & $\begin{array}{l}0.069 \\
(0.61)\end{array}$ & $\begin{array}{r}0.074 \\
(0.65)\end{array}$ & $\begin{array}{l}0.080 \\
(0.82)\end{array}$ \\
\hline HERFIN & $\begin{array}{r}1309.9 \\
(130.2)\end{array}$ & $\begin{array}{r}0.10 \mathrm{E}-04 \\
(1.17)\end{array}$ & $\begin{array}{r}0.19 E-04 \\
(0.61)\end{array}$ & $\begin{array}{r}0.33 \mathrm{E}-04 \\
(1.65)\end{array}$ & $\begin{array}{r}0.32 \mathrm{E}-04 \\
(1.83)\end{array}$ \\
\hline UNDER 18 & $\begin{array}{r}29.0 \\
(2.83)\end{array}$ & $\begin{array}{r}0.78 \mathrm{E}-03 \\
(2.12)\end{array}$ & $\begin{array}{r}0.11 \mathrm{E}-02 \\
(2.88)\end{array}$ & $\begin{array}{r}0.12 \mathrm{E}-02 \\
(2.97)\end{array}$ & $\begin{array}{r}0.86 \mathrm{E}-03 \\
(1.37\end{array}$ \\
\hline OVER64 & $\begin{array}{r}12.1 \\
(3.15)\end{array}$ & $\begin{array}{r}0.57 \mathrm{E}-03 \\
(1.47)\end{array}$ & $\begin{array}{r}0.48 \mathrm{E}-03 \\
(1.23)\end{array}$ & $\begin{array}{r}0.45 E-03 \\
(1.14)\end{array}$ & $\begin{array}{r}0.10 \mathrm{E}-03 \\
(0.16)\end{array}$ \\
\hline LT9ED & $\begin{array}{r}23.0 \\
(8.45)\end{array}$ & $\begin{array}{r}0.11 \mathrm{E}-02 \\
(5.63)\end{array}$ & $\begin{array}{r}0.85 \mathrm{E}-03 \\
(4.26)\end{array}$ & $\begin{array}{r}0.68 \mathrm{E}-03 \\
(3.30)\end{array}$ & $\begin{array}{r}0.20 \mathrm{E}-03 \\
(0.67)\end{array}$ \\
\hline HSDROP & $\begin{array}{r}22.1 \\
(3.79)\end{array}$ & $\begin{array}{r}0.99 \mathrm{E}-03 \\
(3.35)\end{array}$ & $\begin{array}{r}0.12 \mathrm{E}-02 \\
(4.00)\end{array}$ & $\begin{array}{r}0.11 \mathrm{E}-02 \\
(3.65)\end{array}$ & $\begin{array}{r}0.63 \mathrm{E}-03 \\
(1.53)\end{array}$ \\
\hline COLLGRAD & $\begin{array}{r}10.3 \\
(5.26)\end{array}$ & $\begin{array}{r}0.15 \mathrm{E}-03 \\
(0.61)\end{array}$ & $\begin{array}{r}0.84 \mathrm{E}-04 \\
(0.32)\end{array}$ & $\begin{array}{r}0.13 \mathrm{E}-03 \\
(0.41)\end{array}$ & $\begin{array}{r}-0.42 \mathrm{E}-03 \\
(1.05)\end{array}$ \\
\hline MALELF & $\begin{array}{r}55.6 \\
(3.53)\end{array}$ & $\begin{array}{r}0.17 \mathrm{E}-02 \\
(6.42)\end{array}$ & $\begin{array}{r}0.18 \mathrm{E}-02 \\
(6.39)\end{array}$ & $\begin{array}{r}0.17 \mathrm{E}-02 \\
(5.97)\end{array}$ & $\begin{array}{r}0.57 \mathrm{E}-03 \\
(1.32)\end{array}$ \\
\hline
\end{tabular}


TABLE 2 (Continued)

Unemployment Equation Econometric Estimates (absolute value of t-statistics in parentheses)

\begin{tabular}{|c|c|c|c|c|c|}
\hline VARIABLE & $\begin{array}{c}\text { MEAN } \\
\text { (STD DEV) } \\
\text { (1) }\end{array}$ & $\begin{array}{l}\text { OLS-I } \\
\text { (2) }\end{array}$ & $\begin{array}{c}\text { OLS-II } \\
\text { (3) }\end{array}$ & $\begin{array}{c}\text { OLS-III } \\
\text { (4) }\end{array}$ & $\begin{array}{c}\text { RANDOM } \\
\text { EFFECTS } \\
(5)\end{array}$ \\
\hline FEMWCHU6 & $\begin{array}{r}16.7 \\
(6.71)\end{array}$ & $\begin{array}{r}0.29 \mathrm{E}-03 \\
(3.34)\end{array}$ & $\begin{array}{r}0.32 \mathrm{E}-03 \\
(3.64)\end{array}$ & $\begin{array}{r}0.32 \mathrm{E}-03 \\
(3.71)\end{array}$ & $\begin{array}{r}0.28 \mathrm{E}-03 \\
(3.06)\end{array}$ \\
\hline HOMES & $\begin{array}{r}56.8 \\
(8.55)\end{array}$ & $\begin{array}{r}0.25 E-03 \\
(1.69)\end{array}$ & $\begin{array}{r}0.22 \mathrm{E}-03 \\
(1.42)\end{array}$ & $\begin{array}{r}0.27 \mathrm{E}-03 \\
(1.67)\end{array}$ & $\begin{array}{r}0.21 \mathrm{E}-03 \\
(0.69)\end{array}$ \\
\hline BORNINST & $\begin{array}{r}77.0 \\
(13.63)\end{array}$ & $\begin{array}{r}0.27 \mathrm{E}-05 \\
(0.04)\end{array}$ & $\begin{array}{r}0.53 E-04 \\
(0.67)\end{array}$ & $\begin{array}{r}0.36 \mathrm{E}-04 \\
(0.45)\end{array}$ & $\begin{array}{r}0.40 \mathrm{E}-04 \\
(0.25)\end{array}$ \\
\hline REGION_1 & $\begin{array}{l}0.094 \\
(0.29)\end{array}$ & & $\begin{array}{r}0.12 \mathrm{E}-01 \\
(0.94)\end{array}$ & $\begin{array}{r}0.11 \mathrm{E}-01 \\
(0.83)\end{array}$ & $\begin{array}{r}0.13 \mathrm{E}-01 \\
(1.02)\end{array}$ \\
\hline REGION_2 & $\begin{array}{l}0.069 \\
(0.25)\end{array}$ & & $\begin{array}{r}0.19 \mathrm{E}-01 \\
(2.96)\end{array}$ & $\begin{array}{r}0.19 \mathrm{E}-01 \\
(3.08)\end{array}$ & $\begin{array}{r}0.21 \mathrm{E}-01 \\
(2.49)\end{array}$ \\
\hline REGION_3 & $\begin{array}{l}0.088 \\
(0.28)\end{array}$ & & $\begin{array}{r}0.13 \mathrm{E}-01 \\
(1.05)\end{array}$ & $\begin{array}{r}0.78 E-02 \\
(0.63)\end{array}$ & $\begin{array}{r}0.52 \mathrm{E}-02 \\
(0.38)\end{array}$ \\
\hline REGION_4 & $\begin{array}{l}0.088 \\
(0.28)\end{array}$ & & $\begin{array}{r}0.62 \mathrm{E}-04 \\
(0.00)\end{array}$ & $\begin{array}{r}0.53 \mathrm{E}-03 \\
(0.08)\end{array}$ & $\begin{array}{r}0.12 \mathrm{E}-02 \\
(0.15)\end{array}$ \\
\hline REGION_5 & $\begin{array}{l}0.082 \\
(0.27)\end{array}$ & & $\begin{array}{r}-0.72 \mathrm{E}-02 \\
(1.79)\end{array}$ & $\begin{array}{r}-0.58 \mathrm{E}-02 \\
(1.45)\end{array}$ & $\begin{array}{r}-0.47 E-02 \\
(0.68)\end{array}$ \\
\hline REGION_6 & $\begin{array}{l}0.126 \\
(0.33)\end{array}$ & & $\begin{array}{r}-0.21 \mathrm{E}-02 \\
(3.60)\end{array}$ & $\begin{array}{r}-0.20 \mathrm{E}-01 \\
(3.45)\end{array}$ & $\begin{array}{r}-0.23 \mathrm{E}-01 \\
(3.07)\end{array}$ \\
\hline REGION_7 & $\begin{array}{l}0.075 \\
(0.26)\end{array}$ & & $\begin{array}{r}-0.18 \mathrm{E}-01 \\
(3.54)\end{array}$ & $\begin{array}{r}-0.19 E-01 \\
(3.78)\end{array}$ & $\begin{array}{r}-0.20 \mathrm{E}-01 \\
(2.54)\end{array}$ \\
\hline REGION_8 & $\begin{array}{l}0.101 \\
(0.30)\end{array}$ & & $\begin{array}{r}-0.67 \mathrm{E}-02 \\
(1.39)\end{array}$ & $\begin{array}{r}-0.13 E-02 \\
(0.23)\end{array}$ & $\begin{array}{r}-0.15 E-02 \\
(0.20)\end{array}$ \\
\hline REGION_9 & $\begin{array}{l}0.120 \\
(0.32)\end{array}$ & & $\begin{array}{r}-0.35 E-02 \\
(0.83)\end{array}$ & $\begin{array}{r}-0.39 \mathrm{E}-02 \\
(0.95)\end{array}$ & $\begin{array}{r}-0.52 E-02 \\
(0.73)\end{array}$ \\
\hline REGION_10 & $\begin{array}{l}0.088 \\
(0.28)\end{array}$ & & $\begin{array}{r}-0.22 \mathrm{E}-03 \\
(0.43)\end{array}$ & $\begin{array}{r}-0.28 \mathrm{E}-02 \\
(0.53)\end{array}$ & $\begin{array}{r}-0.30 \mathrm{E}-02 \\
(0.42)\end{array}$ \\
\hline HDLT9ED*EMP & $\begin{array}{r}0.634 \\
(1.013)\end{array}$ & & & $\begin{array}{r}0.73 \mathrm{E}-02 \\
(3.08)\end{array}$ & $\begin{array}{r}0.73 \mathrm{E}-02 \\
(3.39)\end{array}$ \\
\hline REGION 8*EMP & $\begin{array}{r}0.160 \mathrm{E}-02 \\
(0.590 \mathrm{E}-02)\end{array}$ & & & $\begin{array}{r}-0.39 \\
(2.08)\end{array}$ & $\begin{array}{r}-0.40 \\
(2.49)\end{array}$ \\
\hline Time Effects Significant & & YES & YES & YES & YES \\
\hline F (Employment Restriction) & & 1.04 & 0.93 & 0.69 & \\
\hline F (Region Effects) & & & $5.22^{2}$ & $5.54^{2}$ & \\
\hline $\begin{array}{l}\text { LaGrange Multiplier Test } \\
\text { (Random Effects) }\end{array}$ & & & & & $408.9^{2}$ \\
\hline $\begin{array}{l}\text { Hausman t-statistic } \\
\text { (EMPLOY) }\end{array}$ & & & -0.06 & 0.12 & -0.07 \\
\hline $\begin{array}{l}\text { Hausman t-statistic } \\
\text { (CRIME) }\end{array}$ & & & 0.24 & 0.11 & -0.40 \\
\hline R-SQUARED & & 0.316 & 0.332 & 0.336 & 0.329 \\
\hline
\end{tabular}

2Statistically significant at or below the 0.001 level. 
counties in Georgia (except employment) and the time series variation for 19801993. The means do not represent state averages, however, since they are unweighted averages. The means of the dummy variables are the proportion of Georgia counties that take on a value of one for that variable. Ordinary least squares estimates of three specifications of equation (1) are given in columns (2)(4). Column (5) presents the results of random effects estimation. Corresponding $\mathrm{t}$-statistics appear below each coefficient in parentheses in columns (2)-(5). Also, at the bottom of each column are the results of relevant hypothesis tests.

From column (2), we see that employment growth significantly reduces unemployment. A 1 percent differential in employment growth reduces unemployment by approximately two-tenths of a percentage point after two years (obtained by summing the employment coefficients). ${ }^{5}$ The relatively low value suggests that there are significant labor force participation rate and/or migration rate responses to employment growth. Yet, unemployment could be affected differently, depending on the source of employment growth. Specifically, employment growth could be due to the county being in a region that had a mix of relatively fast-growing industries nationally, or alternatively, due to the county's being in a region experiencing large idiosyncratic growth. Nevertheless, an F-test shown at the bottom of column (2) failed to reject the null hypothesis of equality of these two employment effects on unemployment, which contrasts with the findings from a panel of states (Partridge and Rickman, 1995a). ${ }^{6}$ The other study found that a 1 percent increase in employment growth that arose from a state's mix of industries had a greater effect on unemployment than comparable employment growth that was idiosyncratic. The difference in findings may be due to the use of counties within Georgia in this study, in which industry structure is more similar within Georgia than it is across states.

After controlling for employment growth and other county characteristics, the dummy coefficients suggest that the Atlanta metropolitan area and other metropolitan areas have lower unemployment, and central city counties have higher unemployment than the rest of Georgia. Nonetheless, these effects are not significant at any conventional level. Most of the other characteristics of counties are significant determinants ( $\mathrm{p}=.10$ or lower, based on two-tailed t-tests) of county unemployment: CRIME, AFRAM, FARMSHR, MANUSHR, CONSTSHR, UNDER 18, LT9ED, HSDROP, MALELF, FEMWCHU6, HOME5.

However, the estimates reported in column (2) may be biased because of possible omitted unmeasured regional effects. Such omitted effects include unmeasured amenity differentials, wage rates, institutional differences, or cultural differences across regions within the state. Therefore, a dummy variable is added for each region in Georgia except Region 11, which will be captured in the con- 
stant term. Thus, the remaining cross-sectional variation that will be reflected in the coefficients is within region variation across counties.

The results obtained with this specification are shown in column (3). The Fstatistic reported at the bottom of column (3) indicates that the region effects are jointly significant. Also, the estimated coefficients for the other variables differ somewhat from those reported in column (2). A one-percent differential growth in employment now leads to a 0.27 percentage point reduction in unemployment after two years. Moreover, a Hausman t-test (reported at the bottom of column 3) of the potential endogeneity of employment to the unemployment rate indicates that the potential bias from ignoring the endogeneity is not statistically significant. $^{7}$

Similarly, the results for the URBAN variables differ. The Atlanta dummy variable becomes negative and significant when the region dummies are added. However, since most counties in Atlanta are also part of Region 3 (fourteen of the twenty), the combined intercept shift for most of the Atlanta counties is the coefficient associated with the Region 3 dummy variable added to the estimated Atlanta effect: $0.013-0.0087=0.0043 .^{8}$ For the Atlanta counties in Regions 1,2 and 4, the combined intercept shifts are $0.0033,0.0103$ and -0.0086 , respectively. That is, all else being equal, most counties in the Atlanta metropolitan area have higher unemployment than the omitted region (Region 11). Similarly, since Regions 5, 6, 7, 8,9 and 10 have negative fixed effects, Atlanta's unemployment is also generally higher than it is in these regions. Moreover, given that all Region 3 counties are in the Atlanta metro area, the negative Atlanta coefficient indicates that, all else equal, unemployment is lower in the outlying Atlanta counties (i.e., outside Region 3). The estimated effect for the other metropolitan areas is still insignificant and close to zero. Thus, other metropolitan areas on average do not have lower unemployment than other counties in their respective regions. The same can be said for a central city county relative to other counties in its metropolitan area and region.

Most of the other results remain unaffected, with few exceptions. Of particular interest is the significant effects on unemployment of the proportion of a county's adult population having less than a high school degree. A one-standard deviation increase in the adult population with less than a ninth grade education increases unemployment by 0.72 percentage points. Similarly, a one-standard deviation increase in the adult population that completed the ninth grade but did not finish high school increases unemployment by 0.45 percentage points. This suggests that stimulating employment alone will not solve the unemployment problem in many counties. Higher educational achievement is one reason that the Atlanta and Athens metropolitan areas have lower unemployment rates than the other metropolitan areas and the rural areas. Moreover, because of the inclusion of 
employment growth in the equation, these coefficients are net of the effect that educational achievement has on reducing unemployment through stimulating employment growth.

The crime rate also significantly increases the unemployment rate. A onestandard deviation increase in the crime rate increases unemployment by 0.26 percentage points. Moreover, as reported in column (2), a Hausman t-test indicates that potential bias arising from unemployment's influence on crime is not statistically significant. ${ }^{9}$ Thus, the sign of the crime coefficient suggests that crime acts more as a producer disamenity than as a consumer disamenity. This also confirms the findings of a study of unemployment using a panel of states (Partridge and Rickman, 1995a), which found that crime increased the unemployment rate, and the potential endogeneity of crime with unemployment did not significantly bias the regression estimates.

The employment shares for Services and Trade become significant with the addition of region dummies, and the employment share for Construction becomes insignificant. Counties in regions with higher employment shares in Agriculture, Manufacturing, Services and Trade have lower unemployment. Having lived in the same home for the last five years (HOME5) becomes insignificant with the addition of region dummies. Moreover, BORNINST is insignificant with or without region dummies. This might be explained by native residents having better labor market information and employers believing that these residents are less likely to quit (Hanson and Pratt, 1992), leading to less employment matching problems. Reduced matching problems would lower the unemployment rate, offsetting the increases in unemployment that occur with limited geographic mobility.

The percent of the population that is African-American is positively related to the unemployment rate. A one-standard deviation increase in the AfricanAmerican proportion of the population increases the unemployment rate by 0.69 percentage points. This is in contrast to the findings of Goss et al. (1994), who found that after controlling for geographic mobility, there was no statistical difference in unemployment duration between whites and nonwhites. Yet, we indirectly control for limited geographic mobility through the inclusion of HOME5 and BORNINST. Thus, there may be unemployment differences across race that cannot be attributed to differences in geographic mobility. Nevertheless, the results also contrast with Partridge and Rickman (1995a), who, using a panel of states, found that race did not affect state unemployment rates.

Other demographic characteristics of a county's population also affect its unemployment rate. A one-standard deviation increase in the male share of the labor force increases unemployment by 0.64 percentage points. It appears that unemployed males have a greater attachment to the labor force. Similarly, a one- 
standard deviation increase in the proportion of females with children six years old or younger increases unemployment by approximately two-tenths of a percentage point. This suggests that the availability of affordable child care affects unemployment among women.

An examination of the individual region coefficients suggests additional explanations for unemployment differences across Georgia. After accounting for the other county characteristics, Region 2 has significantly higher unemployment, while Regions 5, 6 and 7 have significantly lower unemployment. Region 5 encompasses the Columbus metropolitan area, Macon is in Region 6 and the Augusta-Aiken metropolitan area is in Region 7. Thus, it is possible that metropolitan areas contribute to lower unemployment in neighboring nonmetropolitan counties, all else being equal. An alternative, more plausible explanation given the results for the URBAN variables, is that the different coefficients reflect household amenity differentials. For example, Region 2 is in the mountainous area of northern Georgia, and Regions 8 and 11 contain the coastline in southeastern Georgia. Thus, it is possible that with higher levels of household amenities, Regions 2, 8 and 11 have more unemployment, all else equal, while lower amenity levels in Regions 5, 6 and 7 lead to lower unemployment rates.

A further policy issue of interest is the possibility of differences in unemployment responses to employment growth. For example, metropolitan areas may have greater gross migration flows; thus, their unemployment rates may be less affected by employment changes. In addition, employment growth may not affect all skill levels equally. Therefore, we included in another specification the interaction of average employment growth (EMP) (averaged over the current year and two lagged years) with ATLMETRO, OTHMETRO, CENTRAL, REGION_1, REGION_2, REGION_3, REGION_4, REGION_5, REGION_6, REGION_7, REGION_8, REGION_9, REGION_10, the sum of LT9ED and HSDROP (HDLT9ED), and COLLGRAD. However, only two of the interactions were individually significant: REGION_8*EMP and HDLT9ED*EMP. Moreover, based on joint F-tests, the following groups of interactions were insignificant: all interacted terms together; ATLMETRO*EMP, OTHMETRO*EMP and CENTRAL*EMP jointly; and all region interaction terms together. The results for the other variables are qualitatively unaffected with the inclusion of all the interacted terms and the results of hypothesis tests reported in column (3) are unchanged.

Therefore, only the individually significant interaction terms are included in the final specification, with the resulting estimates reported in column (4). The coefficient on HDLT9ED*EMP is positive and significant. This suggests that fewer benefits accrue to less educated unemployed residents from employment growth than on average. Using the coefficients in column (4) and the statewide 
high school attainment level in Georgia of 70.9 percent (in 1990), we can determine that a one-percent increase in employment growth reduces unemployment by 0.36 percentage points: negative 0.57 (the sum of the three employment coefficients) less negative 0.21 percentage points (the Georgia high school nonattainment rate multiplied by the coefficient of the interaction term). This is similar to the magnitude reported by Partridge and Rickman (1995a), which was estimated using a panel of states for the nation ( 0.4 percentage points). In addition, unemployment in Region 8 is significantly more responsive to employment growth than the rest of the state. A one-percent increase in employment growth results in a greater reduction in unemployment in Region 8 by an additional four-tenths of a percentage point. However, the net effect in Region 8 counties depends on the educational achievement level. Given a high school attainment rate of 68.6 percent for Region 8, the net effect of one-percent differential employment growth is 0.73 percentage point lower unemployment, approximately double the state average.

As a final specification, a random effects model is estimated to account for potential unmeasured county-specific effects. ${ }^{10}$ These effects could reflect unmeasured county-specific amenity characteristics, wages, industrial structure, or labor-force characteristics that are randomly distributed across counties. Thus, the random effects model produces efficient estimates of the effects of the included explanatory variables.

Column (5) reports the results of random effects estimation of the model specified in column (4). To be sure, the LaGrange Multiplier Test indicates that the random effects are statistically significant. However, most of the coefficients in the random effects model are similar to those in column (4), with the primary difference in results being the loss of significance of several variables. The sum of the coefficients of the employment variables remains roughly the same, with a slight gain in significance. The list of variables that become statistically insignificant includes ATLMETRO, CRIME, FARMSHR, UNDER18, MALELF, HOME5. In addition, LT9ED and HSDROP become insignificant; thus, in terms of statistical significance, their influence is primarily reflected in the interaction term (HDLT9ED*EMP). Nevertheless, based on an F-test, the variables LT9ED, HSDROP, COLLEGE and HDLT9ED*EMP are jointly significant below the 0.01 level. Also, LT9ED, HSDROP and COLLEGE are jointly significant if HDLT9ED*EMP is not included in the equation. Taken together, these tests suggest that education remains a significant factor, although the individual education coefficients are less precisely measured in the random effects model.

Finally, given the random effect estimates in column (5), the unemployment effects of key explanatory variables are calculated for the various areas of Georgia and reported in Table 3. The random effects estimates are chosen because they 
TABLE 3

Predicted Regional Unemployment Effects of Selected Factors (in percent)

\begin{tabular}{lcccccccc}
\hline Region & Employ & Crime & Race & $\begin{array}{c}\text { High } \\
\text { School }\end{array}$ & $\begin{array}{c}\text { College } \\
\text { Educ }\end{array}$ & $\begin{array}{c}\text { Educ } \\
\text { Interact }\end{array}$ & $\begin{array}{c}\text { Females } \\
\text { w/Child }\end{array}$ & $\begin{array}{c}\text { Fixed } \\
\text { Effect }\end{array}$ \\
\hline Reg 1 & -0.64 & -0.18 & -0.17 & 0.74 & 0.44 & 0.13 & 0.16 & 1.30 \\
\hline Reg 2 & -1.00 & -0.25 & -0.34 & 0.62 & 0.32 & 0.17 & 0.15 & 2.10 \\
\hline Reg 3 & -1.09 & 0.16 & 0.62 & -0.22 & -0.30 & -0.07 & 0.19 & 0.50 \\
\hline Reg 4 & -0.49 & -0.11 & 0.29 & 0.61 & 0.14 & 0.07 & 0.14 & 0.10 \\
\hline Reg 5 & 0.06 & -0.08 & 1.09 & 0.44 & 0.28 & -0.01 & 0.18 & -0.50 \\
\hline Reg 6 & -0.14 & -0.08 & 1.07 & 0.39 & 0.28 & 0.01 & 0.16 & -2.30 \\
\hline Reg 7 & -0.36 & -0.08 & 1.19 & 0.31 & 0.18 & 0.03 & 0.22 & -2.00 \\
\hline Reg 8 & -0.78 & -0.03 & 0.96 & 0.33 & 0.22 & 0.04 & 0.20 & -0.20 \\
\hline Reg 9 & 0.06 & -0.04 & 1.32 & 0.60 & 0.34 & -0.01 & 0.17 & -0.50 \\
\hline Reg 10 & -0.52 & -0.04 & 0.79 & 0.67 & 0.37 & 0.09 & 0.19 & -0.30 \\
\hline Reg 11 & -0.55 & -0.08 & 0.46 & 0.43 & 0.33 & 0.06 & 0.18 & 0.00 \\
\hline Atlanta & -1.05 & 0.14 & 0.58 & -0.19 & -0.25 & -0.10 & 0.20 & -0.80 \\
\hline Fulton Cty & -1.09 & 0.70 & 1.74 & -0.05 & -0.47 & -0.04 & 0.14 & -0.00 \\
\hline Other Metro & -0.24 & 0.06 & 1.00 & 0.18 & 0.08 & 0.02 & 0.20 & -0.20 \\
\hline Central & -0.62 & 0.42 & 1.47 & 0.07 & -0.19 & 0.01 & 0.16 & -0.00 \\
\hline & & & & & & & & \\
\hline
\end{tabular}

are efficient. In addition, since most of the random effects estimates in column (5) are smaller in absolute value, their use provides conservative estimated effects. The effects of employment are based on average employment over the sample period, whereas the effects of the other variables are based on 1990 values. Moreover, for purposes of comparison, the explanatory variables are differenced from U.S. averages. Thus, the reported effects are relative to the nation. Finally, since the data are at the county level, county labor force is used to weight the independent variables to obtain values for each of the eleven regions, metro Atlanta, the average of the other metropolitan areas, and the average of central city counties.

From Table 3, we can discern the reasons for lower unemployment in greater Atlanta and higher unemployment in other parts of the state. For example, the largest employment effects on unemployment are for Regions 2 and 3, which had approximately a 1 percent reduction in unemployment relative to the national average. Greater Atlanta also had approximately 1 percent lower relative unemployment because of relative employment growth in the area. Based on corresponding region employment growth, other metropolitan areas on average experienced reductions in relative unemployment of approximately one-quarter of a percentage point and central city counties had lower relative unemployment of about six-tenths of a percentage point. Specifically, Fulton County, which con- 
tains the central city of Atlanta, had lower unemployment of over 1 percent because of its relative employment growth. Region 8 also benefitted greatly from employment growth. Recall that the unemployment effect of a one-percent differential growth in employment was greater for Region 8. Only Regions 5 and 9 had higher unemployment because of employment growth below the national average over the period.

The Atlanta metro area also benefitted from high education achievement levels. Because of its higher high school attainment rate, metro Atlanta had a 0.19 percentage point lower unemployment rate. In addition, unemployment is estimated to be one-quarter of a percentage point lower in metro Atlanta than the national average because of its high proportion of college graduates. Other metropolitan areas have higher unemployment because of both high school and college attainment rates below the national average. Central city counties benefit only from their proportion of college graduates, with Fulton County benefitting more than any other area. In many other regions of Georgia, however, lower educational achievement levels increased unemployment, sometimes more than offsetting the benefit of robust employment growth. Finally, the effects of education through its interaction with employment growth generally led to small increases in unemployment in Georgia, all else equal.

Offsetting the benefits of employment growth and education that Atlanta enjoys is the effect of higher crime rates. Crime contributed to an increase in relative unemployment of 0.14 percentage points in greater Atlanta. Moreover, crime increased relative unemployment by 0.70 percentage points in Fulton County and 0.42 percentage points in central city counties on average. Other metropolitan areas on average had a crime rate equal to that of the nation, while the remaining regions tended to have less crime than the national average.

Similarly, demographic characteristics affect the unemployment rate. Nationwide, African-Americans are more likely to be unemployed, particularly in inner cities. Thus, it is not surprising that a central city county, all else equal, has 1.47 percentage points higher unemployment because of its larger proportion of African-Americans, with the effect for Fulton County equal to 1.74 percentage points. In addition, Regions 5, 6, 7 and 8 all had unemployment effects of greater than one percentage point due to their population proportions of AfricanAmericans. Another factor contributing to higher unemployment in Georgia is its proportion of females (both married and unmarried) with children six years old or younger. The differential unemployment effect ranges from 0.14 percentage points in Region 4 to 0.22 percentage points in Region 7. Central city counties and metropolitan areas in general do not differ greatly from the rest of the state in this respect. 
Finally, the regional fixed effects (i.e., the coefficients on the regional and URBAN dummy variables) reveal that once the unemployment effects of employment growth and other factors are accounted for, Atlanta, the other metropolitan areas, and central city counties do not have significantly lower unemployment. ${ }^{11}$ For example, an Atlanta county in Region 3 has only 0.3 percentage points lower unemployment than Region 11 ( -0.8 added to 0.5$)$ and has higher unemployment than Regions 5-10, all else being equal. Similarly, the insignificance of the variables measuring area attachment suggests that there are also no inherent reasons why rural nonmetropolitan counties have higher unemployment.

\section{v. SUMMARY AND CONCLUSION}

Using county-level panel data for Georgia, we examined the issue of uneven growth within state economic development. Specifically, we addressed the question of whether unbalanced employment growth was the underlying cause for differential unemployment rates across Georgia, or whether there were other natural rate or equilibrium factors. Our findings suggest that although differential employment growth contributes to area unemployment differences, other factors were at least as important. If Georgia's robust employment growth was to slow to the national average, Georgia's unemployment rate would go from being below the national average to above it.

Policy implications of the results are that to even out and permanently reduce unemployment in Georgia, the low education attainment levels need to be increased in most parts of Georgia; affordable day-care for working women with young children is needed; and higher unemployment among African-Americans needs to be addressed. Alternatively, higher crime rates and location-specific amenity levels prevent unemployment from being lower than it already is in metro Atlanta and neighboring counties. Therefore, low crime rates are a potential selling point for the other parts of Georgia, particularly for counties outside metropolitan areas. Finally, after controlling for characteristics associated with urbanization, unemployment was not significantly lower in urban areas than in the rest of the state. Thus, besides the possibility that employment growth may be higher in urban areas, there appears to be no unemployment benefit to enhancing the urban areas of Georgia versus the rural areas. 


\section{ENDNOTES}

1. For example, Regions 1 and 2 in North Georgia had almost the highest unemployment rates in 1980 . Now, these regions have among the lowest unemployment rates.

2. In regressions not shown, the unemployment effects of employment growth are almost identical to those reported at the county level when the region unemployment rates are used as the dependent variable and the independent variables are also defined for the eleven regions. Thus, we may have confidence in the use of employment growth at the eleven-region level in the county unemployment equations.

3. The other metropolitan areas (MSAs) of Georgia are Albany, Athens, Augusta-Aiken, Columbus, Macon and Savannah.

4. The industry classifications used to calculate the Herfindahl index are two-digit manufacturing industries; transportation and public utilities; trade; finance, insurance and real estate; services; state and local government; and federal government.

5. Employment lags of up to four years were tried. However, the third-year lag was insignificant when added to the two-year lagged model and the fourth year lag was insignificant when added to the third-year lagged model, with individual t-statistics in each case near zero.

6. The industry mix and state idiosyncratic employment variables were based on the concepts of the shift-share model. The industry mix component is the employment growth that would occur if the county's (using employment at the eleven-region level) industries grew at their respective national rates minus total U.S. employment growth. Idiosyncratic growth is the difference between total differential employment growth, less industry mix employment growth. The industry classifications used are given in Endnote 4. The F-test was a test of the null hypothesis that the coefficients on the separate employment variables were equal. Failure to reject the null hypothesis supports just generically including employment growth in the equation and not distinguishing the source of employment growth (i.e., industrial mix and idiosyncratic).

7. The Hausman test creates predicted values for the possible endogenous variables from an instrumental variable regression. These predicted values are then included as additional variables in the regression specification where the $t-$ statistics from these predicted variables are the test statistics. The list of instruments used in the employment regression included all exogenous variables in the equation (i.e., all variables except the crime rate) plus the distance of the county seat of each county to a major metropolitan area-Atlanta, Augusta-Aiken, Columbus, Savannah and Jacksonville, Florida-(Ambrose and Springer, 1993 call these 
strategic urban centers), population density, road mileage density, the number of physicians per person, the number of hospitals per person, and the number of international manufacturing facilities located in the county per person.

8. Three Atlanta metropolitan area counties are located in Region 4, two are in Region 1 and one county is in Region 2.

9. The Hausman test and list of instruments are the same as those used for employment described in Endnote 7.

10. Since many of the variables are cross-sectional or have limited time series variation, and fixed effects estimation utilizes time series variation only for each cross-section unit, we decided upon random effects estimation. Moreover, many fixed effect differences are captured in the region effects. Nevertheless, it should be noted that the random effects estimates can be calculated as a weightedaverage of the fixed effects estimates and the ordinary least squares estimates (Judge et al. 1982, p. 494). The weight is determined by the ratio of the fixed effects standard error relative to the between estimator standard error. If the two standard errors are equal, indicating that the fixed effects did not add any explanatory power, random effects becomes ordinary least squares. On the other hand, as the fixed effects error approaches zero, random effects estimation becomes fixed effects estimation.

11. The F-statistic for the null hypothesis that Fulton County has the same fixed effect as central city counties on average (in regressions not shown) is $0.010,0.036$, and 0.13 for the specifications in columns (2)-(4), respectively. Thus, Table 3 specifies the central city-county fixed effect for Fulton County.

\section{REFERENCES}

Ambrose, Brent W., and Thomas M. Springer. "Spatial Variation of Nonmetropolitan Industrial Location." Journal of Real Estate Finance and Economics. 1993 (7): 17-27.

Bartik, Timothy J. Who Benefits From State and Local Economic Development Policies? Kalamazoo, MI: Upjohn Institute, 1991.

"Who Benefits from Local Job Growth: Migrants or the Original Residents?" Regional Studies. 1993 (27): 297-311.

Blanchard, Olivier J., and Lawrence F. Katz. "Regional Evolutions." Brookings Papers on Economic Activity. (1) 1992: 1-75.

Bolton, Roger. "'Place Prosperity vs People Prosperity' Revisited: An Old Issue with a New Angle." Urban Studies. April 1992 (29): 185-203.

Carlino, Gerald A., and Edwin S. Mills. "The Determinants of County Growth." Journal of Regional Science. February 1987 (27): 39-54. 
Douglas, Stratford, and Howard J. Wall. "'Voting with Your Feet' and the Quality of Life Index: A Simple Non-Parametric Approach Applied to Canada." Economic Letters. 1993 (42): 229-236.

Gepfert, Ken. "Southeast Counties Pay the Price of Prosperity." Wall Street Journal. October 12, 1994, p. S1.

Goss, Ernest P., Chris Paul and Al Wilhite. "Duration of Unemployment: Geographic Mobility and Selectivity Bias." Review of Regional Studies. Fall 1994 (24): 127-142.

Hall, Robert. "Turnover in the Labor Force." Brookings Papers on Economic Activity. (3) 1972: 709-764.

Hanson, Susan, and Geraldine Pratt. "Dynamic Dependencies: A Geographic Investigation of Local Labor Markets." Economic Geography. 1992 (68): 373405.

Herzog, Henry W., and Alan M. Schlottmann. "Labor Force Migration and Allocative Efficiency in the United States: The Roles of Information and Psychic Costs." Economic Inquiry. July 1981 (19): 459-475.

. "The Metro Rating Game: What Can Be Learned from the Recent Migrants?" Growth and Change. 1986 (17): 37-50.

. "Valuing Amenities and Disamenities of Urban Scale: Can Bigger Be Better?" Journal of Regional Science. August 1993 (33): 145-165.

Judge, George G., R. Carter Hill, William E. Griffiths, Helmut LGtkepohl and Tsoung-Chao Lee. Introduction to the Theory and Practice of Econometrics. 1982 (New York: John Wiley \& Sons).

Katz, Lawrence F. and Kevin M. Murphy. "Changes in Relative Wages, 19631987: Supply and Demand Factors." Quarterly Journal of Economics. February 1992 (107): 35-78.

Katz, Lawrence F. and Lawrence H. Summers. "Industry Rents: Evidence and Implications." Brookings Papers on Economic Activity. Microeconomics 1989: 209-290.

Malizia, Emil E. and Shanzi Ke. "The Influence of Economic Diversity on Unemployment and Stability." Journal of Regional Science. May 1993 (64): 221-235.

Marston, Stephen T. "Two Views of the Geographic Distribution of Unemployment." Quarterly Journal of Economics. February 1985 (100): 57-79.

McGee, Robert T. "State Unemployment Rates: What Explains the Differences?" Federal Reserve Bank of New York Quarterly Review. Spring 1985 (10): 2835.

Partridge, Mark D., and Dan S. Rickman. "Differences in State Unemployment Rates: The Role of Labor and Product Market Structural Shifts." Southern Economic Journal, July 1995 (62): 89-106. 
- "The Dispersion of U.S. State Unemployment Rates: The Role of Market and Non-Market Factors." Unpublished Manuscript. 1995b.

Salwen, Kevin G. "Back to Life: Second Tier Cities Finally Join the Region's Boom." Wall Street Journal. February 1, 1995: S1, S3.

Stiglitz, Joseph E. "The Causes and Consequences of the Dependence of Quality on Price." Journal of Economic Literature. March 1987 (25): 1-48.

Summers, Lawrence H. "Why is the Unemployment Rate so very High Near Full Employment?" Brookings Papers on Economic Activity. (2) 1986: 339-383. The Governor's Development Council. Building a New Economic Engine for the 21st Century: Strength From Diversity. Atlanta, Georgia, January 1994. 
